\title{
Marketing For Life In The Economic Recession Time
}

Orose Leelakulthanit, National Institute of Development Administration, Thailand Boonchai Hongcharu, National Institute of Development Administration, Thailand

\begin{abstract}
One of the roles marketing contributes to the society is to improve the consumer well-being through the acquisition and possession of economic goods. This study attempts to investigate this role when subjective well-being or life satisfaction is considered in the difficult time of economic recession. From the part-whole perspective, life satisfaction can be broken down into satisfaction with thirteen domains of life. The multiple regression is run in order to determine the relationship between the satisfaction with these thirteen domains of life as well as household income and overall life satisfaction. The results suggest that consumer well-being in terms of satisfaction with material possession has a positive impact on life satisfaction along with satisfaction with work, self, family, personal health and the objective indicator of economic well-being which is household income.
\end{abstract}

Keywords: Marketing; Life satisfaction; Recession; Consumer well-being; Quality of life

\section{INTRODUCTION}

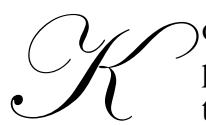

otler (1986) viewed marketing as having evolved historically from a production orientation, through a product orientation, through a selling orientation, through a marketing orientation, and is evolving towards a quality of life (QOL) orientation. The product orientation holds that "consumers will favor those products that are available and highly favorable, and therefore management should concentrate on improving production and distribution facilities". The product orientation posits that "consumers will favor those products that offer the most quality, performance, and feature, and therefore the organization should devote its energy to making product improvements". The selling orientation holds that "consumers will not buy enough of the organization's products unless the organization undertakes a substantial selling and promotion effort". The marketing orientation holds that "the key to achieving organizational goals consists in determining the needs and wants of target markets and delivering the desired satisfactions more effectively and efficiently than competitors". Kotler (1986) defined marketing effectiveness in terms of the QOL concept: The organization's task is to determine the needs, wants, and interests of target markets and to deliver satisfactions more effectively and efficiently than competitors in a way that preserves or enhances the consumer's and society's well-being. A primary marketing objective of QOL marketers is directed to enhance a well-being dimension of a target segment of consumers. This is done by matching organizational skills and resources in the service of targeted consumers. Thus, QOL marketers develop products, services or programs that not only satisfy consumers needs, but also enhance one or more dimensions of their well being (Sirgy, Samli \& Meadow 1982).

The acquisition and possession of goods and services by individuals represent two of the most basic ways marketing influences peoples' lives (Day 1978, 1987). Activities associated with the acquisition of goods and services center around the exchange of goods between seller and buyer. The availability of such merchandise as food and medicine, the prices of goods and services, and the physical condition of the retail store represent factors that enhance or inhibit the acquisition of goods and services by an individual. How satisfied an individual is with the acquisitiveness domain of life may influence how satisfied she or he is with life in general. Possession of goods and services, in contrast, is concerned with the collection of objects maintained by an individual, such as his or her living quarters (that is, houses and apartments), cars, clothing, appliances, savings and investments. Material possessions 
tend to provide functional value and symbolic value to the owners. The degree of satisfaction with possessions may influence how satisfied the individual is with life in general.

This study seeks, in the context of an economic recession, (1) to investigate the effect of the acquisition experience of individuals and material possessions - domains of life that are most directly affected by marketing on QOL; (2) to determine the importance of these domains of life relative to other aspects of peoples' lives, such as work life, social life, spiritual life, and self-development as well as an objective indicator of economic well-being, namely, household income; and (3) to model QOL based on a part-whole framework that views satisfaction with life in general as a function of satisfaction with specific domains of life.

\section{CONCEPTUAL FRAMEWORK}

From the perspective of macro-consumer behavior, consumption is merely one small aspect of human life (Belk 1987). This view is congruent with a part-whole perspective which suggests that life, as a general construct, consists of various specific domains. That is to say, when someone says that he or she is satisfied with his or her life it may mean that he or she has just bought a new house or gotten a promotion. In the terms of state theory, we are happy because of an accumulation of happy moments (Lewinsohn \& MacPhillamy 1974, Chekola 1975, Lewinsohn \& Amenson 1978).

The identification of important domains of life is inevitably somewhat arbitrary. Although a list of areas of life's activities may not be exhaustive, it should be broad enough, at least, to cover most of the domains of life utilized in major studies of the QOL such as Andrews \& Withey (1976), Campbell, Converse \& Rodger (1976), Liu (1976), Campbell (1981). With this objective in mind, thirteen separate domains of life's activities have been identified by Day (1987) and adapted by the author. They are as follows: (1) family life, (2) work life, (3) social life, (4) leisure/recreation, (5) personal health, (6) health care, (7) purchase and consumption of goods and services, (8) material possessions, (9) self-development, (10) spiritual life, (11) life in Thailand, (12) Thai government, (13) Bangkok administration. It should be noted that not everybody shares the same domains. For instance, some people are not married whereas others are.

For each domain, a set of particular aspects of each domain (its subdomains) can also be identified in such a way that the set includes the specific activities related to that domain which best illustrate the nature of its activities or aspects (Day 1987). In sum, life satisfaction is determined by the degree of satisfaction with thirteen domains of life which, in turn, are further characterized by various subdomains.

The satisfaction or dissatisfaction with a subdomain of life is conceptualized as the discrepancy between the perceived subdomain and a personal standard of comparison. This standard of comparison may include the achievement of aspirations (Michalos 1983), what relevant others have (Michalos 1983), what the best one has had in the past (Michalos 1983) and what one deserves (Walster, Berscheid \& Walster 1976). A positive discrepancy creates a satisfaction with the subdomain whereas a negative discrepancy causes a dissatisfaction with the subdomain. For instance, a village man may be quite satisfied with the assortment of goods offered in a small retail store whereas a city man who applies a standard based on a large department store in mind may be quite dissatisfied with that same store.

\section{HOUSEHOLD INCOME}

At the national level, there are several studies which reveal that the nations' wealth is positively correlated with subjective ratings of well-being (Diener, Diener \& Diener 1995; Diener \& Oishi 2000). Multiple studies have examined this association, and it is quite clear that there is a relatively strong correlation between national levels of income and well-being (Deaton 2008, Helliwell 2008, Stevenson \& Wolfers 2008). The observed correlation between nations' income and average life satisfaction judgments stands somewhere between $r=.6$ and $r=.8$. The correlations that are found in such studies should be seen as a lower estimate of the true correlation because it is likely to be attenuated by measurement error. Thus as predicted, income is consistently and strongly linked with higher levels of subjective well-being. 
Results from individual-level analyses are rather more complicated. As with nation-level effects, there are strong theoretical reasons to believe that income will be associated with well-being, at least at lower levels of the income range. Results consistently show this to be the case (Easterlin 1974). Most nationally representative studies, along with meta-analyses of existing studies, show that there are small to moderate correlations between income and well-being (i.e., rs around .20) (Diener \& Oishi 2000; Diener, Suh, Lucas \& Smith 1999; Schimmack 2009). Importantly, although the correlations do vary somewhat from study to study, and although many researchers have described these effects as small, the correlations are almost never negative. One reason why we might obtain consistently positive yet small correlations is that the true correlation is higher than that typically found, but it is attenuated by random measurement error. As noted earlier, random error will reduce the magnitude of correlations, but it does not change the sign of a correlation. Thus, one reason why correlations at the individual level might be weaker than correlations at the national level is that random error attenuates correlations at the individual level more than at the national level.

\section{METHODOLOGY}

\section{Sampling}

Five hundred individuals who were twenty-one years of age or older and living in households in Bangkok, Thailand were interviewed personally during a recession time. They were selected by a two-stage cluster (area) sampling using census data obtained from National Statistics Office as a sampling frame. The first stage involved a random sampling of one block each from all 50 administrative districts. The second stage involved sampling every fifth household after randomly selecting the first household within each block until the total of ten household within each block were achieved. The response rate was $64.02 \%$

\section{Measures of Overall Life Satisfaction}

Multiple-item measures were employed to avoid item response bias. Four scales were used to measure overall life satisfaction: the verbally anchored seven-point Delighted-Terrible Scale, the seven-point Smiling/Frowning Faces scale, the verbally anchored seven-point "Completely Satisfied to Completely Dissatisfied Scale," and the nine-point Ladder Scale adapted from Cantril (1965). Andrews and Withey (1976) report that these scales ranked very high in terms of reliability and validity among a total of 68 measures of quality of life examined. Several other studies have demonstrated the convergent validity of the scales (Andrews \& Mckennell 1980, Atkinson 1982, Horley \& Brian 1985). The result of the study by Leelakulthanit, Day and Walters (1991) and the present study also show the scales to be highly valid and reliable (Appendix 1).

\section{Satisfaction with the Domains of Life}

A seven-item ( $1=$ extremely pleased; $7=$ extremely displeased $)$ scale was used to measure satisfaction with each of the domains of life (Day 1987). Multiple-item measures were employed to measure satisfaction with different domains. Seven items or subdomains were identified for the marketing-related domain of Acquisition/Consumption, while 5 subdomains were employed to measure satisfaction with Material possessions. Five subdomains were measured for Family Life, 5 for Social Life, 10 for Work Life, 4 for Personal health, 5 for Recreation and Spiritual Life, 6 for Self-development, 5 for Health Care Administration, 6 for life in Thailand, 10 for the Thai Government, and 7 for Bangkok Administration (Appendix 1).

\section{Data Analysis}

A reliability analysis of each of the items (that is, subdomains) was performed by computing the item's Cronbach alpha. Scale items with low inter-item correlations were eliminated. The items were subjected to an exploratory factor analysis with varimax rotation to determine the number of factors underlying the items associated with each domain of life. If the factor analysis results suggested more than one factor, the items which were weakly related to no factors (factor loadings < .35) or which clearly represented more than a single domain would be dropped. The remaining items were refactored until the unidimensionality was obtained. Then, the reliability analyses were conducted again, and the size of reliabilities obtained (in the .7 to .9 range) supports the use of the measures (Nunnally 1978). The reliabilities reported in the present study (Appendix 1) ranging from .67 to .93 
compare very favorably with those reported in past research on quality of life, which were in the .5 to .7 range (Atkinson 1982) and .65 to .88 range (Leelakulthanit, Day \& Walters 1991).

\section{RESULTS}

Thais are almost mostly satisfied with their lives. The mean overall life satisfaction value was 3.28 on the average life satisfaction scale of 7.5 (Appendix 1). They are most pleased with family life (mean $=2.55$ ) and least pleased with the Thai government (mean $=4.06)$. Satisfaction with other domains of life are in between as illustrated in Appendix 1.

The impact of satisfaction with the different domains of life and household income on overall life satisfaction was investigated by performing multiple regression analysis. Values obtained from the scale items (subdomains) associated with a particular domain of life and overall life satisfaction were averaged to form measures of that domain of life and overall life satisfaction. Household income was categorized into two groups by splitting the group at the average household income level of Bangkok residents at 36,000 Baht/month ( $\$$ US $1=30$ Baht). The multiple regression was run by regressing overall life satisfaction on satisfaction with thirteen domains of life as well as categorical household income.

The results of this regression as shown in Table1 suggested that satisfaction with Family Life, Work Life, Personal Health, Self-development, Material Possessions and monthly household income have the positive influences on overall life satisfaction. That means the more satisfied people were with their family, work, personal health, self-development and material possessions, the more they would be satisfied with their own lives. Likewise, the higher the household income, the more satisfied people would be with their lives. It should be noted that multicollinearity was not likely to be a problem because the magnitude of variance inflation factors associated with each independent variables was far less than ten (Wetherill, Duncombe, Kenward, Köllerström, Paul \& Vowden, 1986).

The relative effect of satisfaction on the different domains of life was investigated. Together, the 13 domains of life and the household income accounted for $27 \%$ of the variance in life satisfaction (R-square $=.27$ ). The standardized parameter estimates indicate the relative impact of the various domains of life and household income on satisfaction with life as a whole (Table 1). The standardized estimate for Work Life was highest at .21, indicating that Work Life was the most important factor affecting overall life satisfaction. The coefficients for satisfaction with Self-development, Material Possessions, Family Life, Household Income and Personal Health were around 0.1, indicating that they were approximately equally important in affecting satisfaction with Life in General.

Table1: Results of Multiple Regression Analysis of Overall Life Satisfaction on Satisfaction With Specific Domain of Life and Household Income

\begin{tabular}{|c|c|c|c|c|c|c|}
\hline & \multicolumn{2}{|c|}{ Unstandardized Coefficients } & \multirow{2}{*}{\begin{tabular}{|c|} 
Standardized Coefficients \\
Beta
\end{tabular}} & \multirow[t]{2}{*}{$\mathbf{T}$} & \multirow[t]{2}{*}{ Sig. } & \multirow{2}{*}{$\frac{\text { Collinearity Statistics }}{\text { VIF }}$} \\
\hline & $\mathbf{B}$ & Std. Error & & & & \\
\hline (Constant) & 1.332 & .255 & & 5.230 & $.000^{* *}$ & \\
\hline Family & .130 & .069 & .108 & 1.870 & $.062 *$ & 1.608 \\
\hline Social life & .057 & .074 & .044 & .774 & .440 & 1.578 \\
\hline Work & .215 & .060 & .212 & 3.579 & $.000 * *$ & 1.691 \\
\hline Pers. Health & .078 & .045 & .087 & 1.715 & $.087 *$ & 1.236 \\
\hline Recreation & .002 & .068 & .001 & .025 & .980 & 1.577 \\
\hline Spiritual Life & .000 & .065 & .000 & .004 & .997 & 1.515 \\
\hline Self & .125 & .070 & .116 & 1.804 & $.072 *$ & 1.994 \\
\hline Health Care & -.046 & .049 & -.054 & -.938 & .349 & 1.580 \\
\hline Consumption & .100 & .069 & .080 & 1.453 & .147 & 1.471 \\
\hline Mat.Possn. & .111 & .065 & .110 & 1.711 & $.088^{*}$ & 2.002 \\
\hline Life in Thailand & -.018 & .062 & -.019 & -.289 & .772 & 1.984 \\
\hline Government & -.012 & .049 & -.015 & -.249 & .803 & 1.727 \\
\hline Bkk Adm. & -.004 & .056 & -.004 & -.069 & .945 & 1.949 \\
\hline Household Inc. & -.188 & .088 & -.104 & -2.136 & $.033 * *$ & 1.140 \\
\hline
\end{tabular}

$\mathrm{R}^{2}=.265 \quad \mathrm{R}^{2}=.236 \quad \mathrm{~F}_{14,485}=9.148 \quad \mathrm{P}=.000$

$*$ Significant at $\alpha \leq .1 \quad * *=$ Significant at $\alpha \leq .05$ 


\section{CONCLUSION}

In recession time, marketing has a positive impact on Thai lives through their satisfaction with material possessions. Thais felt that their material possessions especially owning cars and having savings and investments contributed significantly to their satisfaction with life in general (Appendix 2), while satisfaction with acquisition/consumption of goods and services had no effect on individuals' overall satisfaction with life. Several non-marketing domains of life also had a positive influence on Thai lives. Satisfaction with work, self, family and personal health created the satisfaction with overall lives of Thais.

Economic well-being as indicated by household income had a positive impact on overall life satisfaction as well. The source of income earned through work life was found to be very important to overall life satisfaction of Thais (Appendix 2). The demonstrated effect of wealth through possessing the big ticket items (cars, houses, appliances, and so forth) contributed to Thai senses of general well-being.

During economic recession, the new senses of well-being came from satisfaction with work and personal health, while satisfaction with material possessions, family and self-development was found to have a similar positive contribution to overall life satisfaction as in the normal economic situation early on (Leelakulthanit, Day \& Walters 1991). Logically, people are likely to be more concerned with working during economic recession and cannot afford to be sick in this difficult time.

\section{LIMITATIONS AND DIRECTIONS FOR FUTURE RESEARCH}

Certain limitations of this research will be discussed. These limitations will also shed some lights on the future research. First, the samples were collected in Bangkok which is an urban area where people are generally wealthier and better educated than those in the rural area. They may not be the good representations of Thais. Future researches may extend to the rural areas and cover every region of Thailand. The variation in life satisfaction according to the regions and even provinces will provide an insight to the marketers and policy makers. Second, Thailand may represent a case of developing country where a certain stage of marketing and economic development has been reached and her people's life satisfaction may be different from those in the developed countries. The cross cultural comparisons of marketing for life of countries at various stages of economic development will deserve future research attention. Third, the model only explains $27 \%$ of variance, there still exists a large portion of variance unexplained. Therefore, future researches may consider taking some seemingly important explanatory variables, for instance, ecology or environment, knowledge or education in the regression model. Fourth, the marketing roles as conceptualized tend to be limited only to acquisition and material possessions. It may be interesting to extend them to post consumption which may include repair or maintenance and disposal of the products. Finally, future research of longitudinal study should be conducted in order to see the stabilized and changing effects of marketing domains of life and non-marketing domains of life in relation to overall life satisfaction.

\section{IMPLICATIONS}

Despite of certain limitations, this study suggests some interesting implications to various audiences. For marketing managers, conspicuous consumption of cars is important to consumers' life satisfaction. It means that during recession time, the promotion of possessions of cars will create the sense of people's well-being. This promotion can be done through the minimal down payment and the low or better yet the no interest rate of leasing as well as the considerable amount of rebates given to the car buyers.

Savings and investment tend to be the area of life that creates life satisfaction. It is noteworthy that during recession consumer confidence in the future of economy is vital to consumer spending. Generally, consumers do not want to take risk. Thus, they may end up putting their money in the bank although the interest rate might be low instead of investing in the stock market which looks gloomy. At this difficult time, marketers can be better off by offering the invitation to grand sales which is a win-win strategy of drawing the traffics to the retailers as well as making the consumers' buying worthwhile. The new concern of people for their personal health will give marketers an idea to offer new products and services that will promote the good health for Thais, for instances, the budgeted 
fortified functional drinks, balanced meals and fitness programs might help people stay healthy while they have to go through the economic turmoil.

For policy makers, work life as a source of earning and household income is important to people's life satisfaction. To help workers keep their jobs in the two hardest-hit sectors, namely export and tourism, financial assistance programs seem to be warrant. Job creation through the short term training of unskilled labors deserves the government attention. A long-term training or educational programs for the skilled manpower will also need to be promoted in order to prepare people for the future opportunities when the economy turns out to be right. Small and medium enterprises need to be supported in order to help people to be able to rely on themselves instead of being hired by the big corporations. Since Thailand may not be able to rely on the West especially the U.S. and Europe as the big trading partners as before, there seems to be shift of trade policies to depend on high growth economies nearby, namely, India and China. However, one of the best policies is to be more self-reliant by boosting domestic consumption. Satisfaction with work, self, family and personal health would hopefully be a good starting point to boost up life satisfaction and help people get on with their life amidst the gloomy economic time.

\section{AUTHOR INFORMATION}

Dr. Orose Leelakulthanit is an associate professor of marketing at NIDA Business School, National Institute of Development Administration, Bangkok, Thailand. Her academic research has been in marketing and international business. In a larger context, she has conducted researches dealing with the competitiveness of Thai garment and jewelry industries. From the consumer point of view, her researches tend to lie in the behavioral side of consumers. Recently, besides the quality of life issues, her research interest has been extended to customer value area as well.

Dr. Boonchai Hongcharu is an associate professor of marketing and Dean of NIDA Business School. His research interest is on integrated marketing communications.

\section{REFFERENCES}

1. Andrews, F. M. \& Mckennell, A.C. (1980). "Measures of self-reported well-being: their affective, cognitive, and other components". Social Indicators Research 8 (2) :127-155.

2. $\quad$ Andrews, F.M. \& Withey, S.B. (1976). Social Indicators of Well-being. N.Y.: Plenum Press.

3. Atkinson, T. (1982). "The stability and validity of quality of life measures." Social Indicators Research 10 (February): 113-132.

4. Belk, R.W. (1987). ACR presidential address: Happy thought in advance in consumer research, In M. Wallendorf \& P. Anderson (Eds). Advanced in Consumer Research, Vol.14 Provo, UT: Association for Consumer Research. 1-14

5. $\quad$ Campbell, A. (1981). The Sense of Well-being in America. N.Y. : McGraw-Hill.

6. $\quad$ Campbell, A., Converse, P.E. \& Rodgers, W.L. (1976). The Quality of American Life. New York: Russell Sage Foundation.

7. Cantrill, H. (1965). The Pattern of Human Concerns. New Brunswick, NJ: Rutgers University Press.

8. Chekola, M. G. (1975). The Concept of Happiness. Ph.D. Dissertation., University of Michigan.

9. Day, R. (1978). "Beyond social indicators:, quality of life at the individual level". In R. Fred, D. Hiram \& C. Barksdale (Eds). Marketing and the Quality of Life. Chicago, American Marketing Association. 11-18.

10. Day, R. (1987). "Relationship between life satisfaction and consumer satisfaction". In A. Coskun Samli (Ed). Marketing and the Quality of Life Interface. New York, Quorum Books. 289-311

11. Deaton, A. (2008). "Income, health, and well-being around the world: Evidence from the gallup world poll”. Journal of Economics Perspectives 22 (2): 53-72.

12. Diener, E., Suh, E.M., Lucas, R.E. \& Smith, H.L. (1999). "Subjective well-being: three decades of progress". Psychological Bulletin 125 (2) : 276-302

13. Diener, E., Diener, M. \& Diener, C. (1995). "Factors predicting the subjective well-being of nation". Journal of Personality and Social Psychology 69 (5): 851-864.

14. Diener, E. \& Oishi, S. (2000). "Money and happiness: Income and subjective well-being across nation". In E. Diener, E. M. Suh, (Eds). Culture and Subjective Well-being. Cambridge, MA: The MIT Press. 185-218. 
15. Easterlin, R. (1974). "Does economic growth improve the human lot? Some empirical evidence". In P. David and M. W. Reder. (Eds). Nations and households in Economic Growth: Essays in Honour of Moses Abramovitz. New York: Academic Press, 89-125.

16. Helliwell, J. F. (2008). "Life satisfaction and quality of development". NBER working paper 14507, National Bureau of Economics Research, Inc.

17. Horley, J, \& Brian, R.L. (1985). “Affective and cognative components of global subjective well-being measures”. Social Indicators Research 17 (August): 189-197.

18. Kotler, P. (1986). Principle of Marketing,3rd ed. Englewood Cliffs NJ, CA: Prentice-Hall.

19. Leelakulthanit, O., Day, R. \& Walters, R. (1991).’'Investigating the relationship between marketing and overall satisfaction with life in a developing country". Journal of Macromarketing 11 (Spring):3-23.

20. Lewinsohn, P. M. \& Amenson, C.S. (1978). "Some relations between pleasant and unpleasant events and depression". Journal of Abnormal Psychology 87 (6) : 644-654.

21. Lewinsohn, P. M. \& Macphillamy, D.J. (1974). "The relationship between age and engagement in pleasant activities". Journal of Gerontology. 29 (3) : 290-294.

22. Liu, B.C. (1976). Quality of Life Indicators in U.S. Metropolitan Areas. N.Y.: Prager.

23. Michalos, A. C. (1983). "Satisfaction and happiness in a rural northern resource community". Social Indicators Research 13 (3) : 224-252.

24. Nunnally, J. (1978). Psychometric Theory. 2d ed, New York: McGraw-Hill.

25. Schimmack, U. (2009). "Measuring wellbeing in the SOEP. Schmollers Jahrbuch" Journal of Applied Social Science Studies 129 (2).

26. Sirgy, J.M., Samli, C.A. \& Meadow, L.H. (1982). "The interface between quality of life and marketing: a theoretical framework" Journal of Public Policy and Marketing 1 (1) : 69-84.

27. Stevenson, B. \& Wolfer, J. (2008). "Economic growth and subjective well-being: reassessing the Easterlin paradox". Available from www.ssrn.com/abstract=1121237

28. Walster, E.,Berscheid, E. \& Walster, G.W.(1976). "New directions in equity Research". In L. Berkowitz and E. Walster. (Eds). Advances in Experimental Social Psychology, New York: Academic Press. 1-42

29. Wetherill, G. B., Duncombe, P., Kenward, M., Köllerström, J., Paul, S. R., Vowden, B. J. (1986).

Regression Analysis with Applications. New York: Chapman and Hall. 


\section{APPENDIX 1}

\begin{tabular}{|c|c|c|}
\hline \multicolumn{3}{|c|}{ Dimensionality, Internal Consistency, and Mean of Measures } \\
\hline Domains of life and Their Subdomains & Item with High Loading & Mean \\
\hline 1. Life in General & & 3.28 \\
\hline - delighted - terrible scale & $\mathrm{X}$ & 3.14 \\
\hline - satisfaction Scale & $\mathrm{X}$ & 3.17 \\
\hline - faces Scale & $\mathrm{X}$ & 2.93 \\
\hline - ladder Scale & $\mathrm{X}$ & 3.85 \\
\hline Coeff. Alpha & 0.83 & \\
\hline 2. Family Life & & 2.55 \\
\hline - marriage & & 2.56 \\
\hline - home-life & $\mathrm{X}$ & 2.53 \\
\hline - children, grandchildren & $\mathrm{X}$ & 2.53 \\
\hline - housing & $\mathrm{X}$ & 2.60 \\
\hline - neighborhood & $\mathrm{X}$ & 3.03 \\
\hline - availability of transportation & & 2.78 \\
\hline - parents,brothers,sisters & $\mathrm{X}$ & 2.01 \\
\hline Coeff. Alpha & 0.68 & \\
\hline 3. Social Life & & 2.84 \\
\hline - friends & $\mathrm{X}$ & 2.43 \\
\hline - neighbors and acquaintances & $\mathrm{X}$ & 2.73 \\
\hline - chance to spend time with other people & $\mathrm{X}$ & 2.91 \\
\hline - clubs, social organizations & $\mathrm{X}$ & 3.21 \\
\hline - convenient meeting places & $\mathrm{X}$ & 2.89 \\
\hline Coeff. Alpha & 0.77 & \\
\hline 4. Work Life & & 2.90 \\
\hline - availability of work & $\mathrm{X}$ & 2.38 \\
\hline - working conditions & $\mathrm{X}$ & 2.86 \\
\hline - the people you work with & $\mathrm{X}$ & 2.77 \\
\hline - hours worked & $\mathrm{X}$ & 2.99 \\
\hline - your earnings & $\mathrm{X}$ & 3.13 \\
\hline - your job security & $\mathrm{X}$ & 2.90 \\
\hline - retirement program & $\mathrm{X}$ & 3.43 \\
\hline - autonomy & $\mathrm{X}$ & 2.65 \\
\hline - opportunities of expressing your abilities & $\mathrm{X}$ & 2.90 \\
\hline - advancement opportunities & $\mathrm{X}$ & 3.20 \\
\hline Coeff. Alpha & 0.91 & \\
\hline 5. Personal Health & & 2.80 \\
\hline - wellness & $\mathrm{X}$ & 2.75 \\
\hline - stamina & $\mathrm{X}$ & 2.82 \\
\hline - mobility (ability to get around your own) & $\mathrm{X}$ & 2.60 \\
\hline - appearance & $\mathrm{X}$ & 3.01 \\
\hline Coeff. Alpha & 0.85 & \\
\hline 6. Recreation & & 3.08 \\
\hline - local recreation and physical fitness facilities & $\mathrm{X}$ & 3.11 \\
\hline - access to planes, trains, city and intercitybuses & $\mathrm{X}$ & 3.35 \\
\hline - spectator sports & $\mathrm{X}$ & 3.49 \\
\hline - hobbies & $\mathrm{X}$ & 2.71 \\
\hline - entertainment and cultural events & $\mathrm{X}$ & 2.75 \\
\hline Coeff. Alpha & 0.67 & \\
\hline 7.Spiritual life & & 2.70 \\
\hline - the choices of religious services available to you & $\mathrm{X}$ & 2.61 \\
\hline - freedom to believe as you choose & $\mathrm{X}$ & 2.38 \\
\hline - freedom to attend religious services & $\mathrm{X}$ & 2.39 \\
\hline - the admirability of monks & $\mathrm{X}$ & 3.56 \\
\hline - personal beliefs which guide your life & $\mathrm{X}$ & 2.57 \\
\hline Coeff. Alpha & 0.76 & \\
\hline 8.Self & & 2.76 \\
\hline - achievement of personal goals(self-actualization) & $\mathrm{X}$ & 3.02 \\
\hline - ability to get along with others,social skills & $\mathrm{X}$ & 2.61 \\
\hline - the respect shown to you by others & $\mathrm{X}$ & 2.74 \\
\hline - the level of education you have & $\mathrm{X}$ & 2.87 \\
\hline - level of competence in your trade or profession & $\mathrm{X}$ & 2.72 \\
\hline - the confidence in yourself & $\mathrm{X}$ & 2.56 \\
\hline Coeff. Alpha & 0.85 & \\
\hline
\end{tabular}




\section{APPENDIX 1 Continued}

\begin{tabular}{|c|c|c|}
\hline \multicolumn{3}{|c|}{ Dimensionality, Internal Consistency, and Mean of Measures } \\
\hline Domains of life and Their Subdomains & Item with High Loading & Mean \\
\hline 9.Health Care & & 3.44 \\
\hline - local hospitals and clinics & $\mathrm{X}$ & 2.94 \\
\hline - competence of local doctors & & 2.81 \\
\hline - emergency medical transportation & $\mathrm{X}$ & 3.40 \\
\hline - doctor's fee & $\mathrm{X}$ & 3.55 \\
\hline - hospital charges & $\mathrm{X}$ & 3.62 \\
\hline - prices of medicines and drugs & $\mathrm{X}$ & 3.66 \\
\hline Coeff. Alpha & 0.86 & \\
\hline 10.Consumption & & 3.08 \\
\hline - selection (assortments) of goods in local stores & & 2.61 \\
\hline - quality of goods available in local stores & $\mathrm{X}$ & 2.77 \\
\hline - prices charged in local & $\mathrm{X}$ & 3.26 \\
\hline - stores attractiveness (ambience) of local store & $\mathrm{X}$ & 2.82 \\
\hline - courtesy and helpfulness of store personal & $\mathrm{X}$ & 3.16 \\
\hline - honesty and trustworthiness of store personal & $\mathrm{X}$ & 3.13 \\
\hline - hours that stores are open & $\mathrm{X}$ & 2.83 \\
\hline - after purchase service provided by stores & & 3.43 \\
\hline - refund/replacement of stores & $\mathrm{X}$ & 3.63 \\
\hline Coeff. Alpha & 0.82 & \\
\hline 11.Material Possessions & & 2.80 \\
\hline - house(s)/apartment(s) & $\mathrm{X}$ & 2.52 \\
\hline - your furniture and appliances & $\mathrm{X}$ & 2.68 \\
\hline - private transportation,for instance, $\operatorname{car}(\mathrm{s})$, truck(s) & $\mathrm{X}$ & 2.71 \\
\hline - clothing, accessories and jewelry & $\mathrm{X}$ & 2.79 \\
\hline - savings and investments & $\mathrm{X}$ & 3.24 \\
\hline Coeff. Alpha & 0.84 & \\
\hline 12.Life in Thailand & & 3.65 \\
\hline - the amount of personal freedom you have & $\mathrm{X}$ & 2.64 \\
\hline - the friendliness of Thais & & 2.67 \\
\hline - the commitment of Thais to world peace & $\mathrm{X}$ & 3.61 \\
\hline - the effort of Thais to preserve the natural environment & $\mathrm{X}$ & 4.16 \\
\hline - the quality of public education in Thailand & $\mathrm{X}$ & 3.75 \\
\hline - the quality of law enforcement in Thailand & & 4.77 \\
\hline - the fairness of the legal system in Thailand & $\mathrm{X}$ & 4.55 \\
\hline - the opportunity one has to succeed in life & $\mathrm{X}$ & 3.20 \\
\hline Coeff. Alpha & 0.79 & \\
\hline 13.Thai Government & & 4.06 \\
\hline - internal economic policies & $\mathrm{X}$ & 4.05 \\
\hline - foreign trade policies & $\mathrm{X}$ & 4.05 \\
\hline - international relation policies & $\mathrm{X}$ & 3.82 \\
\hline - position on civil rights & $\mathrm{X}$ & 3.83 \\
\hline - position on military spending & $\mathrm{X}$ & 4.21 \\
\hline - policies to solve the poverty problem & $\mathrm{X}$ & 4.37 \\
\hline - investment promotion policies & $\mathrm{X}$ & 3.87 \\
\hline - public enterprise policies & $\mathrm{X}$ & 4.09 \\
\hline - unemployment policies & $\mathrm{X}$ & 4.44 \\
\hline - education policies & $\mathrm{X}$ & 3.92 \\
\hline Coeff. Alpha & 0.93 & \\
\hline 14.Bangkok Administration & & 3.71 \\
\hline - public safety (police and fire protection) & $\mathrm{X}$ & 3.58 \\
\hline - public services (streets,roads sanitation, water, recreation) & $\mathrm{X}$ & 3.34 \\
\hline - public health services & $\mathrm{X}$ & 3.48 \\
\hline - welfare human services & $\mathrm{X}$ & 3.66 \\
\hline - quality of public education & $\mathrm{X}$ & 3.52 \\
\hline - mass transportation & $\mathrm{X}$ & 3.91 \\
\hline - vendor policies & & 4.20 \\
\hline - flood prevention & & 4.13 \\
\hline - city planning (the control of construction and expansion in Bangkok & $\mathrm{X}$ & 4.46 \\
\hline Coeff. Alpha & 0.88 & \\
\hline
\end{tabular}




\section{APPENDIX 2}

Correlation Between Material Possessions, Work Life, and Overall Life Satisfaction

\begin{tabular}{|l|c|}
\hline Domains of life and Their Subdomains & Correlation \\
\hline Material Possessions & $.27^{*}$ \\
\hline - house(s)/apartment(s) & $.29^{*}$ \\
\hline - your furniture and appliances & $.37^{*}$ \\
\hline - private transportation,for instance,car(s),truck(s) & $.32^{*}$ \\
\hline - clothing, accessories and jewelry & $.34^{*}$ \\
\hline - savings and investments & $.38^{*}$ \\
\hline Work Life & $.32^{*}$ \\
\hline - availability of work & $.30^{*}$ \\
\hline - working conditions & $.22^{*}$ \\
\hline - the people you work with & $.36^{*}$ \\
\hline - hours worked & $.31^{*}$ \\
\hline - your earnings & $.25^{*}$ \\
\hline - retirement program & $.19^{*}$ \\
\hline - autonomy & $.28^{*}$ \\
\hline - opportunities of expressing your abilities & $.38^{*}$ \\
\hline - advancement opportunities & \\
\hline
\end{tabular}

* Correlation is significant at the 0.01 level (2-tailed) 